\title{
POLITIK HUKUM TAX AMNESTY DALAM MENDUKUNG PEMBANGUNAN NASIONAL
}

\author{
RICKY R. HASIBUAN
}

Email : ricky.hasibuan@haspraconsulting.com

\begin{abstract}
Abstrak
Program Tax Amnesty yang diterbitkan melalui Undang-Undang Nomor 11 Tahun 2016 tentang Pengampuanan Pajak merupakan kebijakan besar yang menerobos konsep hukum yaitu "setiap kesalahan harus mendapat hukuman" namun tax amnesty memberikan pengampunan bagi para pengemplang pajak dengan syarat membayar sejumlah denda. Dalam politik hukum Undang-undang Tax Amnesty ini tujuan kemanfaatan menjadi faktor yang paling diutamakan untuk mengumpulkan dana secara instan dalam rangka membiayai negara. Tax amnesty ini lahir karena rasio prediksi realisasi penerimaan pajak terlalu jauh jaraknya sehingga biaya dalam pembangunan nasional tidak tercover oleh pemasukan pajak yang ada. Sebagai upaya untuk menarik dana secara cepat serta dapat menjaring wajib pajak baru, maka program Tax Amnesty sebagai solusi dalam upaya untuk meningkatkan pendapatan nasional.
\end{abstract}

Kata kunci: Politik Hukum, Tax Amnesty, Pembangunan Nasional

\section{A. Latar Belakang Masalah}

Konsepsi negara hukum Indonesia yangberbasis Pancasila telah lama menjadi wacana dalam berbagai forum akademis dan ilmiah yang tidak kunjung selesai dibicarakan dan diperdebatkan. Semua sepakat bahwa konsepsi negara hukum Indonesia berbeda dengan konsepsi rechtstaat maupun rule of law.Konsepsi negara hukum Indonesia memiliki ciri dan karakteristik yang didasarkan pada semangat dan jiwa bangsa (volkgeist) Indonesia, yakni Pancasila. ${ }^{1}$ Menurut Arief Hidayat, meskipun identifikasi dan perumusan ciri negara hukum Indonesia yang berdasarkan Pancasila telah dirumuskan, namun konsepsi negara hukum Pancasila belum diimplementasikan dan dilembagakan dengan baik. Oleh karena itu, perlu ada upaya sistematis dan terstruktur untuk melakukan internalisasi konsep

${ }^{1}$ Arief Hidayat, Membumikan Konsep Hukum Pancasila (Seminar Pancasila Sebagai Philosophice Gronslag), Undip, Semarang, Disampaikan pada acara Seminar Nasional dengan tema," Menjaga dan Mengaktualisasikan Pancasila Sebagai Philosophiche Gronslag Dalam Kehidupan Berbangsa Dan Bernegara", yang diselenggarakan oleh Pusat Kajian Konstitusi Fakultas Hukum Universitas Diponegoro, Semarang, 29 Juni 2013, hlm.1. 
negara hukum Pancasila ke dalam aspek-aspek kehidupan berbangsa dan bernegara, utamanya dalam pembentukan sistem ekonomi Indonesia berdasarkan Pancasila.

Pasal 1 Ayat (3) Undang-Undang Dasar Negara Republik Indonesia (UUD NRI) Tahun 1945 menegaskan bahwa, "Negara Kesatuan Republik Indonesia adalah Negara hukum." Sejalan dengan itu, Soehino menyatakan bahwa, Negara Kesatuan Republik Indonesia berdasarkan Pancasila dan UUD NRI Tahun 1945 adalah Negara Hukum, yaitu negara yang segala aktivitasnya baik yang dilakukan oleh penguasa maupun oleh warga negara harus berdasarkan atas ketentuanketentuanhukum dan atau aturan-aturan hukum. ${ }^{2}$

Konsep sistem ekonomi Indonesia berdasarkan Pancasila menurut Revrisond Baswir ${ }^{3}$ merupakan turunan dari sistem demokrasi ekonomi yang disesuaikan dengan nilai-nilai lokal, dalam ekonomi kerakyatan seperti Indonesia, nilai dan semangat yang diusung adalah kegotong-royongan, kebersamaan, persaudaraan dan rasa senasib sepenanggungan, merupakan pilihan ketiga antara kapitalisme dengan sosialisme yang berusaha menembus dan mengatasi ketimpangan-ketimpangan sosial yang terjadi, komitmen untuk mewujudkan keadilan dan kesejahteraan serta kemakmuran bagi seluruh rakyat Indonesia, telah dituangkan dalam Pembukaan UUD NRI tahun 1945 alinea ke-4 telah tertuang cita-cita Negara Republik Indonesia sebagai tujuan yang dimaksudkan Negara Kesejahteraan di atas, yaitu:

"Melindungi segenap bangsa Indonesia dan seluruh tumpah darah Indonesia dan untuk memajukan kesejahteraan umum, mencerdaskan kehidupan bangsa, dan ikut melaksanakan ketertiban dunia berdasarkan kemerdekaan, perdamaian abadi, dan keadilan sosial, maka disusunlah Kemerdekaan Kebangsaan Indonesia itu dalam suatu Undang-Undang Dasar Negara Indonesia, yang terbentuk dalam suatu susunan Negara Republik Indonesia yang berkedaulatan rakyat dengan berdasar kepada Ketuhanan Yang Maha Esa, Kemanusiaan yang adil dan beradab, Persatuan Indonesia, dan Kerakyatan yang dipimpin oleh hikmat kebijaksanaan dalam Permusyawaratan/Perwakilan, serta dengan mewujudkan suatu Keadilan sosial bagi seluruh rakyat Indonesia".

\footnotetext{
${ }^{2}$ Soehino, Hukum Tata Negara Teknik Perundang-Undangan (Setelah Perubahan Pertama dan Perubahan Kedua Undang-Undang Dasar Negara Republik Indonesia Tahun 1945),(Yogyakarta: BPFE, 2006), hlm.18.

${ }^{3}$ Revrisond Baswir, Demokrasi ekonomi, (Malang: Averroes Press, tanpa tahun), hlm. 59.
} 
Indonesia adalah negara yang berlandaskan pada supremasi hukum dan menjamin keadilan bagi seluruh rakyatnya, artinya segala tindakan alat-alat perlengkapan negara atau penguasa semata-mata berdasarkan hukum atau dengan kata lain diatur oleh hukum, bukan diperintah berdasarkan kesewenang-wenangan penguasa. Hal tersebut sebagai wujud cerminan rasa keadilan bagi pergaulan hidup warganya.Jadi, suatu pemerintahan disuatu negara hukum akan selalu mendahulukan kepentingan rakyatnya, dengan demikian, pemerintah mempunyai konsekuensi yang memaksa turut serta aktif dalam pergaulan sosial bagi semua orang agar tetap terpelihara. Pemerintah yang menganut sistim Negara Kesejahteraan (welfare state) mempunyai tugas yang sangat luas yang meliputi penyelenggaraan kepentingan umum.Keadilan adalah syarat tercapainya hidup, dan merupakan cerminan dari apa yang dimaksud dari cita-cita rakyat yang tertuang dalam negara. Ukuran keadilan menjadi salah satu tolak ukur keberhasilan dalam negara hukum yang mengidamkan tercapainya negara sejahtera.

Pembangunan nasional merupakan wujud dari pelaksanaan sila kelima Pancasila, yaitu Keadilan Sosial Bagi Seluruh Rakyat Indonesia, dalam rangka mencapai tujuan tersebut di atas, negara membutuhkan dana sebagai penyelenggara aktivitas negara dan dana dibutuhkan oleh negara antara lain diperoleh dari pajak. Dengan kata lain untuk mewujudkan cita-cita Bangsa diperlukan partisipasi dan peran serta masyarakat. Oleh karena itu, UndangUndang Republik Indonesia Nomor 25 Tahun 2000 tentang Program Pembangunan Nasional, butir 3.2.1 Program Peningkatan Penerimaan Negara, menyebutkan bahwa:

"Program ini terutama bertujuan meningkatkan efektivitas perpajakan dan sumber-sumber penerimaan bukan pajak. Sasaran yang hendak dicapai melalui program ini adalah meningkatkan penerimaan negara, khususnya penerimaan pajak.Kegiatan pokok yang dilakukan adalah (1) memperluas basis pajak dengan menyederhanakan administrasi pajak, menghilangkan berbagai pengecualian pajak, dan meningkatkan penegakan hukum bagi wajib pajak dan petugas pajak yang melanggar ketentuan perundangundangan perpajakan; (2) mengoptimalkan kepemilikan pemerintah dalam BUMN, dengan menekan kewajiban pemerintah dan meningkatkan manfaat dari kepemilikan tersebut melalui proses privatisasi; (3) menghapuskan secara bertahap pengelolaan dana-dana negara di luar anggaran negara (offbudget)".

Dalam satu dekade terakhir Anggaran Pendapatan dan Belanja Negara 
(APBN) mengalami peningkatan yang sangat besar. Data penerimaan perpajakan dalam APBN 2017 ditetapkan sebesar Rp. 1.499 triliun. Jumlah tersebut jauh lebih besar dari Rp. 259 triliun dibandingkan penerimaan perpajakan dalam APBN yang sudah diaudit oleh Badan Pemeriksa Keuangan (BPK) sebesar Rp. 1.240 triliun. Namun demikian, penerimaan tersebut jauh lebih rendah dibandingkan dengan RAPBN 2016 dan APBN-P 2016 yang masing-masing sebesar Rp. 1.564,4 triliun dan Rp. 1.539,1 triliun. Penerimaan perpajakan pada 2016 ditarget lebih tinggi dibandingkan dengan realisasi 2015 dikarenakan adanya kebjakan tax amnesty yang mulai diberlakukan September 2016 sampai akhir Maret 2017 dengan target pemerintah sebesar Rp. 165 triliun. Jadi target dalam APBN-P 2016 bisa tercapai. Namun apabila gagal, maka shart fall penerimaan pajak seperti tahun 2014 dan 2015 akan terjadi lagi.Dalam tabel berikut disajikan perkembangan APBN selama kurun waktu dari tahun 2013 sampai dengan 2017.

Tabel 1. Proporsi Penerimaan Pajak terhadap Penerimaan Negara Tahun 2013 s.d. 2017.

\begin{tabular}{|c|c|c|c|c|}
\hline & \multicolumn{2}{|c|}{ Jumlah (dalam Triliun Rupiah) } & & Su \\
Tahun Anggaran & $\begin{array}{c}\text { Penerimaan } \\
\text { Negara } \\
\text { mb } \\
\text { er }\end{array}$ & Penerimaan Pajak & Persentase \% & Re \\
\hline 2013 & $1,438,891.10$ & $1,077,306.70$ & $75 \%$ & $74 \%$ \\
\hline 2014 & $1,550,490.80$ & $1,146,865.80$ & alis \\
\hline 2015 & $1,508,020.37$ & $1,240,418.86$ & $82 \%$ & asi \\
\hline 2016 & $1,786,225.00$ & $1,539,166.20$ & $86 \%$ & AP \\
& & & & BN \\
\hline 2017 & $1,750,283.00$ & $1,498,871.00$ & $86 \%$ & AP \\
\hline
\end{tabular}

Sumber: Kementerian Keuangan RI - RAPBN 2017 (data diolah).

Persentase penerimaan perpajakan terhadap total penerimaan dalam negeri dan total penerimaan negara terus meningkat. Pada tahun 2013, share penerimaan perpajakan terhadap total penerimaan negara sebesar $75 \%$ dari total pendapatan dalam negeri. Pada tahun 2017, target share penerimaan perpajakan terhadap total penerimaan negara sebesar $85,63 \%$ dan $83,99 \%$ dari total pendapatan dalam negeri. Target persentase pendapatan pajak terhadap total pendapatan negara dan total pendapatan dalam negeri tahun 2017, lebih rendah dibandingkan dengan 
APBN-P 2016. Dalam APBN-P 2016, target presentase pendapatan pajak terhadap total penerimaan negara sebesar $86,17 \%$ dan $86,17 \%$ dari total pendapatan dalam negeri. Penurunan ini menunjukkan bahwa pemerintah terlihat lebih realistis dalam menetapkan target penerimaan perpajakan di tengah perlambatan ekonomi yang sedang terjadi. ${ }^{4}$

Center of Indonesia Taxation Analysis (CITA) pada tanggal 23 April 2016 mengungkapkan, banyak negara yang tidak berhasil menerapkan kebijakan pengampunan pajak (tax amnesty). Namun, Italia dan Afrika Selatan bisa dijadikan contoh negara yang berhasil menerapkan kebijakan tersebut dan memperoleh hasil yang baik. Direktur Eksekutif CITA, Yustinus Prastowo menilai, Indonesia sedianya bisa mencontoh apa yang dilakukan oleh kedua negara tersebut. Misalnya Italia, sebelum menerapkan tax amnesty, pemerintahnya mengirim intelijen untuk melacak keberadaan dana masyarakatnya yang terparkir di luar negeri.Jadi sebelum amnesty, Italia mengirim intelijen ekonomi untuk ngecek dimana sih uang-uang Italia. 600 miliar Euro ada di Monako dan Vatikan.

Menurutnya, cara tersebut lebih maksimal manfaat yang didapatkan dibanding langsung menerapkan pengampunan pajak. Terbukti, Italia mampu menarik dana masyarakatnya yang terparkir di luar negeri hingga 80 miliar euro. ${ }^{5}$

Tabel 2. Perbandingan Hasil Uang Tebusan dan Deklarasi Harta

\begin{tabular}{|l|l|l|c|}
\hline Negara & Uang Tebusan (IDR) & Negara & $\begin{array}{c}\text { Dekalarasi } \\
\text { Harta } \\
\text { (IDR) }\end{array}$ \\
\hline Irlandia & Rp. 4,9 & Irlandia & Rp. 30,8 \\
\hline India & Rp. 20,8 & & \\
\hline Italia & Rp. 22,4 & & \\
\hline Afrika Selatan & Rp. 2,4 & Afrika Selatan & Rp. 118,1 \\
\hline Jerman & Rp. 13,7 & & \\
\hline
\end{tabular}

${ }^{4}$ Rosan Roeslani, Amnesti Pajak sebagai Momentum Penguatan Fiskal dan Membangun Daya Saing Ekonomii, dalam Djokosoetono Research Center, Amnesti Pajak Efektivitasnya Bagi Pembiayaan Pembangunan Berkelanjutan, (Depok: Badan Penerit Fakultas Hukum Universitas Indonesia, 2016), hlm. 28-29.

${ }^{5}$ Lily Rusna Fajriah, Dua Negara Ini Bisa Jadi Contoh Keberhasilan Tax Amnesty, https://ekbis.sindonews.com/read/1103450/33/dua-negara-ini-bisa-jadi-contohkeberhasilan-tax-amnesty-1461402051, diakses tanggal 14 November 2018, pukul 18.27 WIB. 


\begin{tabular}{|l|l|l|l|}
\hline Belgia & Rp. 7,4 & & \\
\hline Italia & Rp. 60,9 & Italia & Rp. 1.211,8 \\
\hline Spanyol & Rp. 18,2 & Spanyol & Rp. 207,5 \\
\hline Australia & Rp. 8,3 & Australia & Rp. 69,3 \\
\hline Chili & Rp. 20,8 & Chili & Rp. 277,3 \\
\hline Indonesia & Rp. 97,3 & Indonesia & Rp. 3.705,0 \\
\hline
\end{tabular}

Sumber: Data Diolah. ${ }^{6}$

Pencapaian ini menunjukkan amnesti pajak cukup efektif untuk menambah jumlah Wajib Pajak. Buktinya, bahwa sejak berlakunya amnesti pajak telah terdaftar Wajib Pajak baru sebanyak 12.892 wajib pajak. Selain itu, amnesti pajak mampu menjaring data baru dan data informasi hasil amnesti akan menjadi dasar untuk memperluas basis pajak. Hal-hal ini merupakan pra-syarat bagi terbangunnya sistem perpajakan yang berkeadilan dan berkepastian hukum melalui pengampunan pajak. ${ }^{7}$

Hingga detik terakhir 31 Maret 2017, sedikitnya Rp. 4.866 triliun harta dideklarasikan dan terdiri dari Rp. 3.687 triliun deklarasi dalam negeri, Rp. 1.032 triliun deklarasi luar negeri, dan Rp. 147 triliun komitmen repatriasi. Deklarasi harta melampaui target Rp. 4.000 triliun, sedangkan repatriasi hanya tercapai 15\% jauh dibawah target Rp. 1.000 triliun. Uang tebusan yang terkumpul Rp. 135 triliun atau 82\% dari target Rp.165 triliun. ${ }^{8}$

Evaluasi menyeluruh merupakan titik awal yang sangat diperlukan agar kita tidak tersesat menerka arah reformasi perpajakan. Pertama, belum maksimalnya beberapa capaian, khususnya repatriasi dana dan partisipan amnesti. Kedua, amnesti pajak memiliki tujuan utama mengalihkan harta dari luar negeri ke dalam negeri. Artinya, repatriasi adalah sasaran amnesti. Faktanya, pencapaian Rp. 147 triliun-dengan kemungkinan R.p 29 triliun membatalkan repatriasi-menyulitkan upaya menyuntikkan likuiditas pada perekonomian domestik. Apalagi sebenarnya uang tebusan Rp. 135 triliun adalah perpindahan likuiditas dari perbankan ke kas negara. Dengan kata lain, kondisi likuiditas perbankan dan sektor keuangan pascaamnesti masih impas. ${ }^{9}$

${ }^{6}$ Yustinus Prastowo, Pengampunan Pajak Historiografi Perjalanan Amnesti Pajak di Indonesia, Jakarta : Cipta Riset Fiskal, 2017, hlm. 207.

${ }^{7}$ Ibid., hlm. 207.

${ }^{8}$ Ibid. hlm. 233.

${ }^{9}$ Ibid. hlm. 234-235. 
Peningkatan penerimaan negara dari sektor pajak sebagai salah satu sumber pembiayaan yang sangat dimungkinkan dan terbuka luas, didasarkan pada jumlah pembayar pajak dari tahun ke tahun yang diharapkan semakin banyak seiring dengan semakin bertambahnya jumlah penduduk dan meningkatnya kesejahteraan masyarakat. Saat ini pemerintah terus berusaha meningkatkan penerimaan negara dari sektor Pajak, hal ini sangat disadari, mengingat dimasa mendatang penerimaan dari sektor pajak akan merupakan primadona dalam mengisi kas APBN, setelah penerimaan dari minyak bumi dan gas bukan lagi merupakan sektor pendapatan utama yang dapat diandalkan.Salah satu cara untuk meningkatkan penerimaan pajak ini tentunya sangat berkaitan erat dengan berkembang tidaknya dunia usaha di tanah air, apabila dunia usaha mengalami perkembangan, maka penerimaan pajak dapat dipastikan akan meningkat.

Pasal 37A UU No. 6 Tahun 1983 tentang Ketentuan Umum dan Tata Cara Perpajakan sebagaimana telah beberapa kali diubah terakhir dengan UU No. 16 Tahun 2009 menjadi dasar hukum diterapkannya kebijakan yang dikenal dengan sunset policy jilid I. Sedangkan sunsetpolicy jilid II Pasal 36 Ayat (1) huruf a UU KUP yang mengatur tentang kewenangan Direktur Jenderal Pajak karena jabatan atau atas permohonan Wajib Pajak dapat mengurangkan atau menghapuskan sanksi administrasi berupa bunga, denda dan kenaikan yang terutang sesui dengan ketentuan peraturan perundangan perpajakan dalam hal sanksi tersebut dikenakan karena kekhilafan Wajib Pajak atau bukan karena kesalahannya. ${ }^{10}$ Direktur Jenderal Pajak menindak lanjuti dengan menerbitkan surat No. S38/PJ./2008 tanggal 14 Maret 2008 yang berisi instruksi kepada Kepala Kantor Wilayah Direktorat Jenderal Pajak (DJP) dan Kepala Kantor Pelayanan Pajak untuk melaksanakan sejumlah kegiatan sosialisasi sunset policy melalui berbagai cara dan media sesuai dengan situasi dan kondisi setempat. Kebijakan ini merupakan versi mini dari program pengampunan pajak (tax amnesty) yang banyak diminta kalangan usaha.

Sunset policy belum mampu memuaskan semua pihak tetapi kebijakan ini telah menimbulkan kelegaan bagi banyak pihak. ${ }^{11}$ Dalam pelaksanaannya, implementasi perpajakan di Indonesia masih mempunyai beberapa permasalahan utama, yaitu: (1) Kepatuhan Wajib Pajak(WP) masih rendah; (2) Kekuasaan

${ }^{10}$ ATS Consulting, Sunset Policy Jilid I dan Jilid II, https://www.atskonsultama.com/jawaban/sunset-policy-jilid-i-dan-jilid-ii, diakses tanggal 17 Oktober 2018, pukul 16.00 WIB.

11 http://nindityo.com/2008/03/23/sunset-policy-pengampunan-pajak-di-uu-kup-2008/ diakses tanggal 31 Maret 2015. 
Direktorat Jenderal Pajak (DJP) terlalu besar karena mencakup fungsi eksekutif, legislatif, dan yudikatif sehingga menimbulkan ketidakadilan dalam melayani hak WP yang berefek turunnya tingkat kepatuhan; (3) Rendahnya kepercayaan masyarakat terhadap aparatur perpajakan dan kompleksnya aturan perpajakan itu sendiri. ${ }^{12}$ Disebut sunset policy adalah karena kebijakan yang berdasarkan Pasal 37A UU KUP hanya berlaku untuk jangka waktu singkat, yaitu satu tahun di tahun 2008. Sunset sendiri berarti matahari yang hampir tenggelam, dan kebijakan (policy) berakhir pada 31 Desember 2008. Kebijakan selanjutnya untuk memenuhi kebutuhan pembiayaan APBN yang semakin meningkat di tengah program nawacita pemerintah, pemerintah mengeluarkan kebijakan tax amnesty melalui Undang-Undang No. 11 Tahun 2016 tentang Pengampunan Pajak dengan target tebusan sebesar Rp. 165 triliun. Program pengampunan pajak (tax amnesty) yang digulirkan pemerintah sejak Juli 2016, berakhir pada Jumat (31/3/2017) tepat pukul 24.00. Hasilnya, berdasarkan Surat Pernyataan Harta SPH total harta yang dilaporkan para Wajib Pajak mencapai Rp 4.855 triliun. Berdasarkan data dashboardtax amnesty, total harta yang dilaporkan terdiri dari deklarasi harta dalam negeri Rp 3.676 triliun dan harta luar negeri mencapai Rp 1.031 triliun. Penarikan dana dari luar negeri (repatriasi) mencapai Rp 147 triliun. Uang tebusan Rp 114 triliun, ditambah dengan tunggakan dan bukper jadinya Rp 135 triliun. Masih banyak hal-hal yang perlu dikerjakan pemerintah agar prinsip keadilan perpajakan bagi Wajib Pajak tercipta. ${ }^{13}$

Pengampunan pajak berlaku sangat terbatas tidak sampai setahun, tepatnya Sembilan bulan saja, sejak Juli 2016 sampai dengan 31 Maret 2017. Pemerintah tidak akan tinggal diam dan meneruskannya dengan melakukan pengecekan terhadap harta Wajib Pajak, baik yang ada di dalam negeri maupun di luar negeri, yang belum diungkap dalam pengampunan pajak. Terhadap harta-harta yang sudah diungkap dalam pengampunan pajak maka pemerintah tidak mempersoalkannya. Sebagaimana yang telah dijanjikan dalam Undang-Undang No. 11 Tahun 2016, dibebaskan dari pemeriksaan pajak, pemeriksaan bukti permulaan, dan penyidikan tindak pidana dibidang perpajakan. ${ }^{14}$

${ }^{12}$ Ragimun, Peneliti Badan Kebijakan Fiskal Kemenkeu RI, tahun 2016.

${ }^{13}$ Rosan Roeslani, Amnesti Pajak sebagai Momentum Penguatan Fiskal dan Membangun Daya Saing Ekonomi, dalam Djokosoetono Research Center, Amnesti Pajak Efektivitasnya Bagi Pembiayaan Pembangunan Berkelanjutan (Depok: Badan Penerbit Fakultas Hukum Universitas Indonesia, 2016), hlm. 30.

${ }^{14}$ Erna Widjajati, Pengampunan Pajak dalam Rangka Meningkatkan Penerimaan Pajak untuk Pembiayaan Pembangunan, dalam Djokosoetono Research Center, Amnesti Pajak 
Keutamaan dari pengampunan pajak adalah itikad untuk memberikan maaf dan pengampunan dari pemerintah terhadap Wajib Pajak atas kesalahan terdahulu. Beberapa pengampunan pajak yang diberikan oleh pemerintah dalam bentuk pengurangan dan/atau penghapusan pajak terutang serta pengurangan dan/atau penghapusan sanksi administrasi dan sanksi pidana dibidang perpajakan. Karena itu, penelitian ini diharapkan dapat merekonstruksikan model pengampunan pajak yang tepat untuk mendukung pelaksanaan program pengampunan pajak (tax amnesty) agar efektif dalam meningkatkan penerimaan negara, khususnya dalam beberapa indikator, yaitu: 1) meningkatkan jumlah Wajib Pajak; 2) mengungkap subyek pajak dan obyek pajak yang tepat sasaran; 3) meningkatkan kepatuhan Wajib Pajak; 4) mendorong repatriasi harta yang ada berada di luar negeri guna memperbaiki struktur perekonomian dalam upaya meningkatkan pembentukan modal dalam negeri; dan 5) menurunkan jumlah tunggakan pajak.Dengan demikian, amnesti pajak yang diterapkan kali ini, merupakan 'one shoot program' yang hanya diselenggarakan sekali untuk satu generasi dan sebaiknya dimanfaatkan oleh seluruh Wajib Pajak.

\section{B. Metode Penelitian}

Pada penelitian ini menggunakan jenis penelitian deskriptif analitis. Penelitian deskriptif analitis bersifat eksploratif yang lebih menekankan pada studi kasus. Suteki dan Galang Taufani berpendapat bahwa pendekatan kualitatif merupakan tata cara penelitian yang menghasilkan data deskriptif. Penelitian deskriptif yaitu menggambarkan gejala-gejala di lingkungan masyarakat terhadap suatu kasus yang diteliti (studi kasus). ${ }^{15}$ Jenis penelitian yang paling sesuai untuk penelitian kualitatif adalah penelitian studi kasus.

Penelitian kualitatifadalah penelitian yang analisis datanya menggunakan pendekatan kualitatif. Data-data dalam penelitian tersebut tidak berupa angkaangka tapi kata-kata verbal. Definisi penelitian kualitatif menurut Syaodih Sukmadinata adalah suatu penelitian yang ditujukan untuk mendeskripsikan dan menganalisis fenomena, peristiwa aktifitas sosial, sikap, kepercayaan, persepsi, pemikiran orang secara individual maupun kelompok. Sedangkan menurut Bodgan dan Taylor mengemukakan metode kualitatif sebagai prosedur penelitian yang menghasilkan data deskriptif berupa kata-kata atau lisan dari orang-orang dan

Efektivitasnya Bagi Pembiayaan Pembangunan Berkelanjutan (Depok: Badan Penerbit Fakultas Hukum Universitas Indonesia, 2016), hlm. 88-89.

${ }^{15}$ Suteki dan Galang Taufani, Metodologi Penelitian Hukum (Filsafat, Teori dan Praktik), (Depok: RajaGrafindo Persada,2018), hlm. 180. 
perilaku yang dapat diamati. Miles and Huberman metode kualitatif berusaha mengungkap berbagai keunikan yang terdapat dalam individu, kelompok, masyarakat, dan/atau organisasi dalam kehidupan sehari-hari secara menyeluruh, rinci, dalam, dan dapat dipertanggungjawabkan secara ilmiah. ${ }^{16}$

Peneliti hendak meneliti efektivitas keberlakuan atas suatu peraturan perundang-undangan pengampunan pajak (tax amnesty) dan melalui pendekatan penelitian socio legal ini untuk mencari hubungan (korelasi) antara berbagai gejala atau variabel sebagai alat pengumpul data, terdiri dari penelitian lapangan (field research), penelitian dokumen (documentary research), pengamatan (observasi), dan wawancara (interview). Pendekatan studi socio legal ini sangat membantu menjawab keraguan terhadap penerapan pengampunan pajak (tax amnesty) yang telah diterapkan di Indonesia mulai tahun 2017.

Pendekatan hukum doktrinal dan pendekatan hukum empirik dengan berbagai metode "baru", metode socio legal menunjukan ruang-ruang dimana perbincangan mengenai akar pohon ilmu adalah masa lalu ${ }^{17}$ sehingga pendekatan socio legal mengunakan pendekatan hukum doktrinal dan penelitian dapat dijelaskan untuk membantu menjawab keraguan hukum yang terjadi di Indonesia.

\section{Hasil Penelitian Dan Pembahasan}

\section{Politik Hukum Pemungutan Pajak Dan Peneriman NegaraDalam Rangka Akselerasi Pembangunan Nasional.}

Pajak mempunyai fungsi penting dalam kehidupan bernegara khususnya dalam akselerasi pembangunan nasional, yang diantaranya mempunyai fungsi utama, yaitu sebagai (1) fungsi anggaran (budgetair), pajak sebagai salah satu sumber penerimaan negara guna membiayai pengeluaran negara dan kegiatan rutin administrasi pemerintahan; (2) fungsi mengatur (regulerend), pajak digunakan oleh pemerintah untuk mengatur perekonomian melalui kebijakan fiskal, alokasi sumber-sumber ekonomi; (3) fungsi stabilitas, pajak digunakan untuk kebijakan terkait stabilitas harga sehingga inflasi dapat dikendalikan, misalkan dengan mengatur peredaran uang di masyarakat, pemungutan pajak, dan; (4) fungsi redistribusi pendapatan, pajak akan digunakan untuk pembiayaan kepentingan umum termasuk membiayai pembangunan sehingga dapat membuka kesempatan

${ }^{16}$ Suteki dan Galang Taufani, Metodologi Penelitian Hukum (Filsafat, Teori dan Praktik), (Depok: RajaGrafindo Persada,2018), hal. 139.

${ }^{17}$ Sulistyowati Irianto \& Shidarta, Metode Penelitian Hukum, (Jakarta: Yayasan Obor Indonesia,tanpa tahun), hal. 187. 
kerja, yang akhirnya dapat meningkatkan penghasilan masyarakat.

Pemerintah dalam hal ini Direktorat Jenderal Pajak (DJP), sesuai fungsinya mempunyai kewajiban melakukan pembinaan dan penyuluhan terhadap Wajib Pajak, dalam pelaksanaan fungsinya wajib berusaha sebaik mungkin mengembangkan dan terus memperbaharui sistem perpajakan, agar tercipta kesadaran dan kepatuhan sukarela (voluntarary compliance) Wajib Pajak guna membantu pembiayaan pembangunan nasional.

Terciptanya kesadaran dan kepatuhan sukarela Wajib Pajak untuk membayar pajak juga didasarkan pada prinsip-prinsip dalam memungut pajak. Secara umum, kita menerima canon of taxation yang masyhur dari Adam Smith ${ }^{18}$ bahwa "asas pemungutan pajak yang adil harus memperhatikan prinsip keadilan (equity), kepastian hukum (legal certainty), prinsip kenyamanan (convenienceof payment), dan efisiensi." Jauh mundur ke belakang, prinsip keadilan dalam pemungutan pajak ditemukan dalam pemikiran filsuf Yunani Kuno Plato. Plato ${ }^{19}$ mengatakan bahwa "keadilan pajak terjadi apabila orang dalam tingkat penghasilan yang sama membayar pajak yang sama. Atau sebaliknya bagi Plato ketidakadilan terjadi jika pada tingkat penghasilan sama orang menanggung beban pajak yang berbeda." Plato adalah orang pertama yang mengantisipasi gagasan keadilan horisontal dan keadilan vertikal. Aristoteles melanjutkan Plato dengan menegaskan konsep keadilan distributif (iustitia distributiva) yang kemudian dipertajam oleh Thomas Aquinas.

Pada Summa Theologica, Aquinas ${ }^{20}$ menyatakan "prinsip Secundum suum possibilitatem et secundum aequaitatem proportionis", yang menjadi dasar prinsip ability to pay di kemudian hari. Pajak seharusnya tidak sekadar mengatur berapa banyak seseorang dapat berkontribusi, tetapi beban pajak seharusnya bertambah sebanding dengan peningkatan kemampuan membayar. Pandangan Aquinas ini setidaknya kokoh hingga percabangan pemikiran di sekitar abad ke-17. ${ }^{21}$

Prinsip ability to pay menjadi standar keadilan pajak di awal abad modern dan bercabang sejak Thomas Hobbes menjadi semakin meredup

${ }^{18}$ Adam Smith (1776) dalam Yustinus Prastowo, Antologi Perpajakan Indonesia Membedah Kebijakan, Menelisik Reformasi, dan Mengupas Isu Terkini tentang Perpajakan Indonesia, (Pajak: Cita Riset Fiskal, 2017), hlm. 117.

${ }^{19}$ Plato \& Bloom (1968) dalam Yustinus Pratowo, Ibid., 2017, hlm. 118.

${ }^{20}$ Yustinus Pratowo, Ibid., 2017, hlm. 118-119.

${ }^{21}$ Yustinus Pratowo, Ibid., 2017, hlm. 119. 
ketika John Locke pada tahun 1690 yang mendasarkan pemikirannya pada teori kontrak menyatakan bahwa "pemerintah tidak dapat didukung tanpa pungutan yang besar dan ini dibebankan pada setiap orang seturut dengan perlindungan dan biaya pemeliharaan diterima dari pemerintah". Pemikiran Locke diikuti oleh Charles de Mountesquieu yang menyatakan bahwa pajak adalah pembayaran sebagian dari harta seseorang yang menikmati keamanan". Adam Smith yang kemudian terkenal dengan canon of taxation berpandangan serupa bahwa seseorang harus berkontribusi pada pengeluaran publik sebisa mungkin mendekati kemampuannya yaitu sebanding dengan pendapatan dinikmati di bawah perlindungan negara. Sejak saat itulah. Prinsip ability to pay hanya menjadi subordinat benefit principle (prinsip manfaat) yang dirintis John Locke. ${ }^{22}$

Perubahan paradigmatik terjadi melalui John Stuart Mill - tokoh utilitarian Inggris yang paling berpengaruh. Dalam bukunya Priciple of Political Economy, Mill mengatakan bahwa meski pemerintah bertujuan melindungi warganya tetapi pemerintah juga bertanggungjawab melindungi warga yang secara sosial tidak dapat membantu dirinyasendiri. Dengan demikian, pendekatan manfaat mengalami cacat konseptual. Bagi Mill, semua orang berpikir untuk menjalankan kewajibannya secara fair ketika setiap orang telah berkontribusi seturut dimiliki, yakni pengorbanan yang setara bagi obyek bersama. Meskipun Mill setuju dengan prinsip ability to pay, Mill tidak setuju dengan Pajak Penghasilan (PPh) yang bersifat progresif. Mengikuti pendahulunya Jeremy Bentham, Mill mengusulkan pajak atas konsumsi dan hanya menyetujui progresivitas untuk penghasilan tidak kena pajak sebagai standar biaya hidup minimum. ${ }^{23}$

Teori pengorbanan setara dan perdebatan tentang pajak progresif ini kemudian dilanjutkan oleh para ekonom marginalis Inggris seperti Francis J. Edgeworth, Henry Sidgwick, dan Arthur Pigou, serta ekonom Jerman-Austria seperti Adolph Wagner dan Robert Meyer yang memadukan ide pengorbanan marginal yang setara dengan teori hasil lebih yang semakin berkurang. ${ }^{24}$ Ramifikasi pendekatan teoretik terjadi di abad ke-20, ketika para ekonom mulai meninggalkan prinsip ability to pay yakni karena nilai guna pendapatan sebagai indikator pengorbanan individual, tidak dapat diukur secara pasti. Para ekonom kemudian beralih ke pendekatan good tax system atau secara

22, Ibid., 2017, hlm. 119.

${ }^{23}$, Ibid., 2017, hlm. 120.

${ }^{24}$, Ibid., 2017, hlm. 120-121. 
khusus prinsip netralitas dan efisiensi sebagai pondasi pendekatan perpajakan optimal. Sebaliknya, para ahli hukum tetap mengadopsi prinsip ability to pay sebagai standar keadilan pajak dalam kaitannya dengan solidaritas dan redistribusi sosial. ${ }^{25}$

Hal penting yang patut digarisbawahi, semua ahli sependapat bahwa pemungutan pajak harus didasarkan pada prinsip-prinsip keadilan yang meresapi dan mengejawantah dalam peraturan perundang-undangan dan praktik pemungutan pajak. Di sinilah, canon of taxation Adam Smith diterima sebagai formulasi prinsip yang dapat mencakup dan merangkum ikhtiar memungut pajak yang baik.Sejak reformasi perpajakan dengan perubahan ketentuan peraturan perundang-undangan perpajakan pada tahun 1983 yang menggantikan peraturan perpajakan yang dibuat oleh kolonial Belanda (misalnya: Ordonansi Pajak Perseroan (PPs) $1925^{26}$ dan Ordonansi Pajak Pendapatan (PPd) 1944 ${ }^{27}$ merupakan awal dimulainya reformasi perpajakan Indonesia. Di masa pemerintah Orde Lama terdapat beberapa pajak yang pemungutannya tidak berdasarkan Undang-Undang, melainkan hanya berdasarkan Keputusan Presiden atau Keputusan Menteri Keuangan (contoh: Meterai Revolusi, Sumbangan Istimewa atas Harga Tak Gerak). ${ }^{28}$

Pemungutan pajak harus berdasarkan Undang-Undang, karena Pasal 23 Ayat (2) Undang-Undang Dasar Negara Republik Indonesia Tahun 1945(UUD NRI 1945) menentukan demikan, yang merupakan sumber hukum formal

${ }^{25}$ Yustinus Pratowo, Ibid., 2017, hlm. 120.

${ }^{26}$ Undang-Undang No. 22 Tahun 1964 tentang Ordonansi Pajak Perseroan (PPs) 1925, sebagaimana telah diubah dan ditambah, terakhir dengan Undang-undang No. 24 Prp tahun 1959 (Lembaran-Negara tahun 1959 No. 141) diubah dan ditambah sebagai berikut: I.Pasal 4 ditambah dengan satu ayat, ayat (7) yang berbunyi sebagai berikut: "(7) Menteri Urusan Pendapatan, Pembiayaan dan Pengawasan dapat mengadakan peraturan tentang penghitungan laba-kena-pajak cabang-cabang perusahaan tertentu mengingat pada keadaan-keadaan istimewa sekian perseratus dari pada peredaran brutonya". ....".

${ }^{27}$ Undang-Undang Nomor 9 Tahun 1970 tentang Ordonansi Pajak Pendapatan (PPd) 1944, sebagaimana telah diubah dan ditambah dan ditambah terakhir dengan UndangUndang No. 8 tahun 1967 (Lembaran Negara tahun 1967 No. 18) diubah dan ditambah sebagai berikut : I.Pasal 2 ayat (2) huruf a dan b dihapuskan. II. Pasal 2e ayat (2) dihapuskan. III.Pasal 5a ayat (1) seluruhnya diubah sehingga berbunyi sebagai berikut: "Jika dalam melakukan peraturan-peraturan untuk menetapkan pendapatan bersih dalam sesuatu tahun dihitung kerugian, maka kerugian ini dikurangkan dari pendapatan bersih dalam 4 (empat) tahun berikutnya, dimulai dengan tahun pertama dari tahun-tahun itu". ".

${ }^{28}$ Rochmat Soemitro \& Dewi Kania, Asas dan Dasar Perpajakan 1 Edisi Revisi, (Jakarta : Refika Aditma, tanpa tahun), hlm. 7. 
dari pemungutan pajak. Mengutip buku Rochmat Soemitro, bahwa tujuan dari Pasal 23 Ayat (2) UUD NRI 1945 tersirat falsafah pajak yang mendalam, yaitu pajak merupakan peralihan kekayaan dari rakyat kepada pemerintah yang tidak ada imbalannya secara langsung, dapat ditunjuk, maka upaya peralihan kekayaan itu tidak dikatakan sebagai "perampokan" maka disyaratkan bahwa pajak sebelum diberlakukan, harus melalui Dewan Perwakilan Rakyat, yang anggota-anggotanya dipilih secara langsung dan demokratis oleh rakyat, sehingga apabila DPR RI sudah menyetujui undangundang, hal ini berarti bahwa pemungutan pajak sudah disetujui oleh rakyat dan ketentuan DPR itu bersama Presiden yang dituangkan dalam bentuk undang-undang. ${ }^{29}$

Falsafah yang terkandung dalam Pasal 23 Ayat (2) UUD NRI 1945, ternyata sama dengan falsafah yang dianut di Inggris yang berbunyi bahwa "No Taxation Without Representation", dan falsafah pajak Amerika Serikat yang berbunyi bahwa "Taxation Without Representation is Robbery".Indonesia telah mengganti sistem pemungutan pajak, dari sebelum reformasi perpajakan dengan sistem official-assessment menjadi sistem self-assessment, dan tetap diterapkan sampai dengan sekarang. Self-assessment system merupakan sistem pemungutan pajak yang memberikan kepercayaan Wajib Pajak untuk menghitung/memperhitungkan, membayar, dan melaporkan sendiri jumlah pajak terutang berdasarkan peraturan perundang-undangan perpajakan. ${ }^{30}$

Dengan self-assesment system, pemerintah berharap adanya kesadaraan rakyat untuk taat pajak, rakyat harus dijadikan tax minded dan sekaligus tax discipline $e^{31}$ untuk membantu melangsungkan kehidupan negara. Sebaliknya pada sistem official-assessment besarnya pajak yang seharusnya terutang ditetapkan mutlak oleh fiskus, dengan kriteria yaitu:

1) Wewenang menetapkan besaran pajak terutang ada pada fiskus;

2) Wajib Pajak bersifat pasif; dan

3) Utang pajak timbul dengan diterbitkannya surat ketetapan pajak.

${ }^{29} \mathrm{Ibid}, \mathrm{hlm} .8$.

${ }^{30}$ http://dippekade-pakpakbharatkab.blogspot.com/2012/06/sistem-pemungutanpajak-di-indonesia.html diakses tanggal 22 Mei 2015

${ }^{31}$ Ibid, hlm. 5. 
Bagan 1. Self Assessment\& Penegakan Hukum

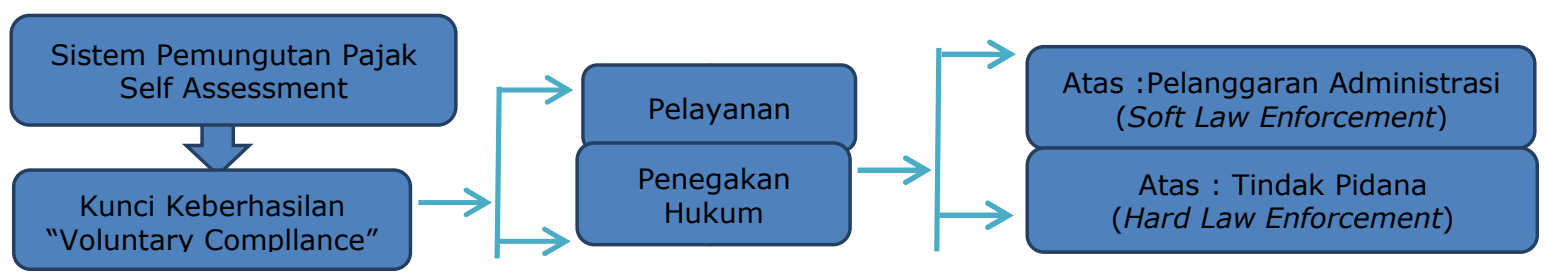

Sistem self assessment dalam Undang-Undang No. 16 Tahun 2009 tentang Ketentuan Umum dan Tata Cara Perpajakan (UU KUP) yang dianut Indonesia, mengandung makna Wajib Pajak telah mengisi dan menyampaikan SPT dengan benar, lengkap dan jelas sesuai dengan ketentuan hukum material dan formal. Dengan kata lain, jumlah pajak yang terutang, yang dilaporkan dalam SPT dijamin oleh undang-undang, sebagaimana ditegaskan dalam Pasal 12 Ayat (2) UU KUP yang berbunyi: "jumlah pajak yang terutang menurut Surat Pemberitahuan yang disampaikan oleh Wajib Pajak adalah jumlah pajak yang terutang sesuai dengan ketentuan perundang-undangan perpajakan". Selanjutnya pada Pasal 12 Ayat (3) disebutkan bahwa: "apabila Direktur Jenderal Pajak mendapatkan bukti bahwa pajak menurut Surat Pemberitahuan sebagaimana dimaksud Pasal 12 Ayat (2) tidak benar, maka Direktur Jenderal Pajak menetapkan pajak terutang”. Dengan demikian, bahwa Direktur Jenderal Pajak tidak dapat melakukan koreksi SPT atas jumlah pajak dengan semata-mata melakukan tafsiran, analisis, angka multiplikator, perbandingan usaha sejenis dan metode pemeriksaan lainnya. Apabila Wajib Pajak keberatan atas surat keputusan yang diterbitkan oleh Direktur Jenderal Pajak, Wajib Pajak dapat mengajukan permohonan keberatan. ${ }^{32}$

Sistem perpajakan yang berlaku di Indonesia adalah self-assessment system, dimana negara memberikan kepercayaan penuh kepada Wajib Pajak untuk mendaftar, menghitung, menyetor, dan melaporkan kewajiban perpajakannya. Untuk dapat menjalankannya dengan baik, maka setiap Wajib Pajak memerlukan pengetahuan pajak, baik dari segi peraturan maupun teknis administrasinya. Agar pelaksanaannya dapat tertib dan sesuai dengan target yang diharapkan, pemerintah telah menyiapkan rambu-rambu yang diatur dalam UU Perpajakan yang berlaku. Dari sudut pandang yuridis, pajak

${ }^{32}$ Nuryadi Mulyodiwarno, Menakar Kesetaraan Hak dan Kewajiban Perpajakn di Indnoesia Seri 2, (Depok: RajaGrafindo Persada, 2018), hlm. 2 
memang mengandung unsur pemaksaan. Artinya, jika kewajiban perpajakan tidak dilaksanakan, maka ada konsekuensi hukum (sanksi pajak) yang bisa terjadi.

Dalam ketentuan perpajakan Indonesia, dikenal dua macam sanksi pajak, yaitu (1) sanksi administrasi dan (2) sanksi pidana. Perbedaan dari kedua sanksi tersebut adalah bahwa sanksi pidana berakibat pada hukuman badan seperti penjara atau kurungan. Pengenaan sanksi pidana dikenakan terhadap siapapun yang melakukan tindak pidana di bidang perpajakan.Pelanggaran terhadap kewajiban perpajakan, sepanjang menyangkut tindakan administrasi perpajakan, dikenai sanksi administrasi dengan menerbitkan Surat Ketetapan Pajak atau Surat Tagihan Pajak, sedangkan yang menyangkut tindak pidana dibidang perpajakan dikenai sanksi pidana.

Agar suatu perbuatan dapat digolongkan ke dalam perbuatan tindak pidana di bidang perpajakan, perbuatan tersebut harus memenuhi unsurunsur sebagai berikut: (a) unsur subyek; (b) unsur perbuatan; (c) unsur akibat; dan (d) unsur kesalahan, apabila terpenuhi maka akan dilakukan penyidikan terhadap Wajib Pajak tersebut. Konsekuensi hukum tersebut adalah pengenaan sanksi-sanksi perpajakan. Pada hakikatnya, pengenaan sanksi perpajakan diberlakukan untuk menciptakan kepatuhan Wajib Pajak dalam melaksanakan kewajiban perpajakannya. Dengan kata lain, sanksi perpajakan merupakan alat pencegah (preventive) agar Wajib Pajak tidak melanggar norma. Itulah sebabnya, penting bagi Wajib Pajak memahami sanksi-sanksi perpajakan sehingga mengetahui konsekuensi hukum dari apa yang dilakukan ataupun tidak dilakukan.

\section{Negara Hukum dan Kepatuhan Warganya Dalam Membayar Pajak}

Penerapan tax amnesty merupakan salah satu upaya pemerintahyangpada dasarnya penerapan kebijakan ini diharapkan dapat meningkatkan jumlah Wajib Pajak. John Hutagaol $^{33}$ menyatakan "pengampunan pajak merupakan kebijakan pemerintah di bidang perpajakan yang memberikan penghapusan pajak yang seharusnya terutang dengan membayar tebusan dalam jumlah tertentu yang bertujuan untuk memberikan tambahanpenerimaan pajak dan kesempatan bagi Wajib Pajak yang tidak patuh (tax evaders) menjadi wajib pajak yang patuh (honest taxpayers),

${ }^{33}$ John Hutagaol, Perpajakan: Isu-Isu Kontemporer, (Yogyakarta : Graha Ilmu, 2007), hlm. 27. 
sehingga diharapkan akan mendorong peningkatan kepatuhan sukarela wajib pajak (taxpayer's voluntarily compliance) dimasa akan datang".

Tax Amnesty sebenarnya dapat dibedakan menjadi soft tax amnesty dan hard tax amnesty. Soft tax amnesty memungkinkan untuk memberikan pengampunan atas sanksi administrasinya, sementara hard tax amnesty memberikan pengampunan atas sanksi pidananya.Tujuan dari pengampunan pajak adalah:

1) Meningkatkan pendapatan negara dalam jangka pendek dan juga meningkatkan kepatuhan Wajib Pajak. ${ }^{34}$

2) Disamping itu akan menurunkan tunggakan pajak, sehingga akan menurunkan biaya penagihan pajak, sehingga akan terjadi penghematan pajak bagi pihak fiskus, dan bagi pihak WP akan semakin sukarela membayar pajak.

Konsep Justification Tax Amnestydiberikan kepada pelaporan sukarela data kekayaan Wajib Pajak yang tidak dilaporkan di masa sebelumnya tanpa harus membayar pajak yang mungkin belum dibayar sebelumnya. Dalam menetapkan perlu tidaknya tax amnesty, perlu dipertimbangkan apa yang menjadi justifikasi dari tax amnesty dan hingga batas mana tax amnesty dapat dijustifikasi. Umumnya, pemberian tax amnesty mempunyai tujuan meningkatkan penerimaan pajak dalam jangka pendek.

Permasalahan penerimaan pajak yang stagnan atau cenderung menurun seringkali menjadi alasan pembenar diberikannya tax amnesty. Hal ini berdampak pada keinginan pemerintahan yang berkuasa untuk memberikan tax amnesty dengan harapan pajak yang dibayar oleh Wajib Pajak selama program tax amnesty akan meningkatkan penerimaan pajak.

${ }^{34}$ Eric Le Borgne, Tax Amnesty : Theory, Trends, and Some Alternatives, (Washington, D.C. USA : International Monetary Fund, 2008), tanpa halaman. 
Tabel 4. Capaian Tax Amnesty Periode I dan II. (Tahun 2016)

\begin{tabular}{|c|c|c|c|c|c|c|c|}
\hline \multirow{2}{*}{$\begin{array}{l}\text { Jenis } \\
\text { Wajib } \\
\text { Pajak }\end{array}$} & \multirow{2}{*}{$\begin{array}{c}\text { Jumlah WP } \\
\text { mengikuti } \\
\text { Tax } \\
\text { Amnesti }\end{array}$} & \multirow[b]{2}{*}{$\begin{array}{l}\text { Pengajuan } \\
\mathrm{SPH}^{35}\end{array}$} & \multirow{2}{*}{$\begin{array}{l}\text { Uang } \\
\text { Tebusan } \\
\text { (triliun } \\
\text { Rp) }\end{array}$} & \multicolumn{4}{|c|}{ Harta Deklarasi dan Repatriasi (triliun Rp) } \\
\hline & & & & $\begin{array}{c}\text { Deklarasi } \\
\text { DN }\end{array}$ & Repatriasi & $\begin{array}{l}\text { Deklarasi } \\
\text { LN }\end{array}$ & Jumlah \\
\hline Badan & 140,836 & 143,521 & 12.69 & 451.66 & 20.03 & 22.92 & 494.61 \\
\hline $\begin{array}{l}\text { Orang } \\
\text { Pribadi }\end{array}$ & 475,045 & 493,831 & 90.35 & $2,166.32$ & 94.13 & 705.73 & $2,966.18$ \\
\hline Jumlah & 615,881 & 637,352 & 103.04 & $2,617.98$ & 114.16 & 728.65 & $3,460.79$ \\
\hline
\end{tabular}

Sumber : Data Statistik tax amnesty 20 Oktober 2017 (Laporan Tahuna DJP 2016).

Program tax amnesty yang dilakukandi Indonesia terbilang sukses dalam meningkatkan penerimaan negara dari sisi perpajakan. Berdasarkan data yang dimiliki oleh Direktorat Jenderal Pajak ada sekitar 51 negara di dunia yang melakukan program tax amnesty. Indonesia termasuk negara yang mampu mengumpulkan data tebusan tax amnesty yang besar. Sampai akhir periode I tax amnesty, total dana tebusan yang berhasil dikumpulkan tercatat Rp. 81,1 triliun atau lebih dari 50 \% dari target dalam APBN-P 2016.

Tabel 5. Capaian Tax Amnesty Periode I, II, III (Per 29 Mei 2017).

\begin{tabular}{|l|l|r|}
\hline \multicolumn{1}{|c|}{ K E T E R A N G A N } & \multicolumn{1}{|c|}{ JENIS WAJIB PAJAK } & J U M L A H \\
\hline \multirow{3}{*}{ Partisipasi Wajib Pajak } & Orang Pribadi & $736.093 \mathrm{wp}$ \\
\cline { 2 - 3 } & Badan & $237.333 \mathrm{wp}$ \\
\cline { 2 - 3 } & Jumlah & $973.426 \mathrm{wp}$ \\
\hline Uang Tebusan (triliun Rp) & 111,54 \\
\hline Surat Setoran Pajak & 1.108 .720 surat \\
\hline Pengajuan Surat Pernyataan Harta & 1.030 .14 surat \\
\hline \multirow{3}{*}{$\begin{array}{l}\text { Harta Yang Diungkapkan } \\
\text { (Triliun Rp) }\end{array}$} & Deklarasi DN & $3.700,80$ \\
\cline { 2 - 3 } & Deklarasi LN & 146,7 \\
\cline { 2 - 3 } & Repatriasi & $1.036,76$ \\
\cline { 2 - 3 } & Jumlah & $4.884,26$ \\
\hline
\end{tabular}

${ }^{35} \mathrm{SPH}$ (Surat Pernyataan Harta) adalah surat yang digunakan oleh Wajib Pajak dalam mengajukan amnesty pajak, antara lain berisi pelaporan harta, utang, serta penghitungan dan pembayaran uang tebusan.

${ }^{36}$ Surat Pernyataan Harta adalah surat yang digunakan oleh wajib pajak untuk melaporkan harta, utang, nilai harta bersih, penghitungan dan pembayaran uang tebusan. 
Keterangan : Sumber Dasboard Amnesti Pajak per 29 mei 2017 (Laporan Kinerja DJP 2017- diolah).

\section{Penegakan Hukum Pajak Dalam Mendukung Pembangunan Nasional}

Penegakan hukum menurut Satjipto Rahardjo ${ }^{37}$, pada hakikatnya mengandung supremasi nilai substansial, yaitu keadilan. Namun, semenjak hukum modern digunakan, pengadilan bukan lagi tempat untuk mencari keadilan (searching of justice). Pengadilan tidak lebih hanya menjadi lembaga yang berkutat pada aturan main dan prosedur. Hukum kemudian tidak lagi dapat menyediakan keadilan sebagai trade mark-nya selama ini. Keadilan telah mati secara dramatis di lembaga-lembaga peradilan di bawah rezim hukum modern. Tidak hanya itu, hukum kemudian dipahami semata sebagai produk dari negara dalam bentuk peraturan perundang-undangan. Lembaga peradilan yang semula sebagai house of justice harus berubah menjadi tempat untuk menerapkan peraturan perundang-undangan dan prosedur.

Penegakan hukum bukanlah semata-mata berarti pelaksanaan perundang-undangan, walaupun di dalam kenyataan di Indonesia kecenderungannya adalah demikian, sehingga pengertian "law enforcement" begitu popular. Selain dari itu, maka ada kecenderungan yang kuat untuk mengartikan penegakan hukum sebagai pelaksanaan keputusan-keputusan hakim. Perlu dicatat, bahwa pendapat-pendapat yang agak sempit tersebut mempunyai kelemahan-kelemahan, apabila pelaksanaan daripada perundangundangan atau keputusan-keputusan hakim tersebut malahan mengganggu kedamaian di dalam pergaulan hidup. Teori bekerjanya hukum dan faktorfaktor yang mempengaruhi penegakan hukum menurut Soerjono Soekanto, ${ }^{38}$ berdasarkan penjelasan-penjelasan tersebut di atas dapatlah ditarik suatu kesimpulan sementara, bahwa masalah pokok daripada penegakan hukum sebenarnya terletak pada faktor-faktor yang mungkin mempengaruhinya. Faktor-faktor tersebut adalah sebagai berikut:

a. Faktor hukumnya sendiri, yang di dalam tulisan ini akan dibatasi pada Undang-Undang saja.

${ }^{37}$ Satjipto Rahardjo, Penegakan Hukum Suatu Tinjauan Sosiologis, (Yogyakarta: Genta Publishing, 2009), hlm. Ix.

${ }^{38}$ Soerjono Soekanto, Faktor-Faktor yang mempengaruhi penegakan hukum, Disampaikan dalam Pidato Pengukuhan dalam Jabatan Guru Besar Tetap pada Fakultas Hukum Universitas Indonesia Rabu, Tanggal 14 Desember 1983, hlm 4-5. 
b. Faktor penegak hukum, yakni pihak-pihak yang membentuk maupun menerapkan hukum.

c. Faktor sarana atau fasilitas yang mendukung penegakan hukum.

d. Faktor masyarakat, yakni lingkungan dimana hukum tersebut berlaku atau diterapkan.

e. Faktor kebudayaan, yakni sebagai hasil karya, cipta dan rasa yang didasarkan pada karsa manusia di dalam pergaulan hidup.

Kelima faktor tersebut di atas saling berkaitan dengan eratnya, oleh karena merupakan esensi dari penegakan hukum, serta juga merupakan tolok ukur daripada efektivitas penegakan hukum. Dengan demikian, maka kelima faktor tersebut akan dibahas di bawah ini, dengan cara mengetengahkan contoh-contoh yang diambil dari kehidupan masyarakat Indonesia. Keberhasilan program tax amnesty tidak hanya berkaitan dengan tingginya uang tebusan. Di tengah ketidakpastian perekonomian global dan menurunnya pertumbuhan ekonomi domestik, tax amnesty mampu memberikan dampak yang positif bagi perekonomian nasional. Tetapi terdapat banyak catatan dalam pelaksanaan tax amnesty temasuk kendala sosialisasi di kantor perwakilan pajak di daerah hingga kesiapan petugas pajak menghadapi lonjakan antrian Wajib Pajak yang ingin mengikuti tax amnesty. Kondisi tersebut hanya permasalahan yang sifatnya teknis. Permasalahan utama dalam program tax amnesty yang berjalan di Indonesia lebih berkaitan dengan lambannya dana repatriasi yang masuk ke Indonesia, gangguan pada likuiditas perbankan, reformasi perpajakan dan fiscal illusion. ${ }^{39}$ Efektivitas pelaksanaan program tax amnesty, ditentukan beberapa indikator yaitu: a) peningkatan jumlah Wajib Pajak; b) memperjelas subyek pajak dan obyek pajak; c) mempercepat dana repatriasi; d) peningkatan kepatuhan Wajib Pajak; dan e) penurunan tunggakan pajak.

a. Peningkatan Jumlah Wajib Pajak

Wajib Pajak adalah orang atau badan yang menurut ketentuan peraturan perundang-undangan perpajakan ditentukan untuk

${ }^{39}$ Rosan Roeslani, Amnesti Pajak sebagai Momentum Penguatan Fiskal dan Membangun Daya Saing Ekonomi, dalam Djokosoetono Research Center, Amnesti Pajak Efektivitasnya Bagi Pembiayaan Pembangunan Berkelanjutan, (Depok: adan Penerbit Fakultas Hukum Universitas Indonesia, 2016), hlm. 37-39. 
melakukan kewajiban perpajakan. ${ }^{40}$ Negara berkembang pada umumnya memiliki jumlah Wajib Pajak orang pribadi yang relatif kecil dibandingkan jumlah penduduk potensial menjadi Wajib Pajak. Perkembangan jumlah Wajib Pajak orang pribadi sebenarnya cukup menggembirakan meski masih didominasi Wajib Pajak orang pribadi karyawan. Tingkat kepatuhan juga menunjukkan peningkatan. Hak yang perlu dikejar adalah Wajib Pajak orang pribadi kaya dan sangat kaya tetapi belum sebagai Wajib Pajak. ${ }^{41}$

Langkah yang dilakukan selama ini, pemberian NPWP dengan pendekatan kekayaan. Hal ini dapat dilakukan melalui kepemilikan rumah, kendaraan, investasi di pasar modal, atau simpanan di bank dan lembaga keuangan lainnya. Perlu dilakukan kerja sama dengan berbagai instansi untuk mendapatkan data sebanyak-banyaknya.

Tabel 6. Jumlah Wajib Pajak Periode 2013 s.d. 2017

\begin{tabular}{|c|c|c|c|c|c|}
\hline \multirow{2}{*}{ Tahun } & \multicolumn{3}{|c|}{ Jumlah Wajib Pajak (\%) } & & $\begin{array}{c}\text { Ratio } \\
\text { Kepatuhan }\end{array}$ \\
\cline { 2 - 4 } & OP & Bendahara & Badan & $\begin{array}{c}\text { Jumlah } \\
\text { Keseluruhan }\end{array}$ & $\begin{array}{c}\text { Menyampaikan } \\
\text { SPT Tahunan } \\
\text { Pph }\end{array}$ \\
\hline 2013 & $89.66 \%$ & $2.01 \%$ & $8.31 \%$ & $28,004,218$ & $60.68 \%$ \\
\hline 2014 & $90.56 \%$ & $1.35 \%$ & $8.09 \%$ & $30,574,428$ & $58.87 \%$ \\
\hline 2015 & $90.60 \%$ & $1.36 \%$ & $8.05 \%$ & $33,336,122$ & $60.42 \%$ \\
\hline 2016 & $90.66 \%$ & $1.33 \%$ & $8.01 \%$ & $36,446,616$ & $60.82 \%$ \\
\hline 2017 & $90,78 \%$ & $1,28 \%$ & $7,95 \%$ & 39.151 .603 & $72,64 \%$ \\
\hline
\end{tabular}

Sumber: Laporan Tahunan DJP Tahun 2013-2017. ${ }^{42}$

${ }^{40}$ Erna Widjajati, Pengampunan Pajak dalam Rangka Meningkatkan Penerimaan Pajak untuk Pembiayaan Pembangunan, dalam Djokosoetono Research Center, Amnesti Pajak Efektivitasnya Bagi Pembiayaan Pembangunan Berkelanjutan, (Depok: Badan Penerbit Fakultas Hukum Universitas Indonesia, 2016), hlm. 83.

${ }^{41}$ Yustinus Prastowo, Antologi Perpajakan Indonesia Membedah Kebijakan, Menelisik Reformasi, dan Mengupas Isu Terkini tentang Perpajakan tentang Perpajakan Indonesia, (Jakarta: Cita Riset Fiskal, 2017), hlm. 60-61.

${ }^{42}$ Tanpa Pengarang, Laporan Tahunan Direktorat Jenderal Pajak Tahun 2013-2017, http://www.pajak.go.id/laporan-tahunan-djp, diakses tanggal 6 Agustus 2018 pukul 09.00 WIB. 
Data menunjukkan korelasi positif antara sistem demokratis dengan naiknya PPh Orang Pribadi. Untuk Indonesia, pada tahun 2016 menunjukkan PPh Orang Pribadi baru 60,82\% dari potensi yang diperkirakan. Pada tahun 2017 menunjukkan PPh orang pribadi mencapai $72,64 \%$ sehingga mengalami kenaikan/penurunanjumlah Wajib Pajak.

\section{b. Subyek Pajak dan Obyek Pajak}

Subjek pajak adalah orang, badan, atau kesatuan lainnya yang memenuhi syarat-syarat subjek, yaitu yang bertempat tinggal atau berkedudukan di Indonesia. Subjek pajak dari pajak langsung adalah tetap, dan dikenakan secara perodik, sedangkan subjek pajak dari pajak tidak langsung adalah tidak tetap, dan hanya dikenakan pajak secara insidental, jika Tatbestand yang ditentukan oleh undang-undang dipenuhi.Pajak yang subjektif (atau pribadi) adalah pajak yang besarnya ikut ditentukan oleh keadaan dan status Wajib Pajak (yaitu bujangan, kawin, kawin dengan anak, dan sebagainya). Pajak yang objektif adalah pajak yang besarnya tidak dipengaruhi oleh keadaan atau status wajib pajak, melainkan ditentukan semata-mata oleh keadaan objek, seperti Cukai Tembakau, Pajak Kendaraan Bermotor, Pajak Pertambahan Nilai, dan sebagainya. ${ }^{43}$ Jadi subyek pengampunan pajak adalah Wajib Pajak orang pribadi atau badan dengan nama dan dalam bentuk apapun baik telah maupun yang belum terdaftar sebagai Wajib Pajak. Subyek pajak dibedakan menjadi 2 (dua), yaitu subjek pajak dalam negeri, subjek pajak luar negeri (Pasal 2 Ayat (4) UU PPh) dan Percepatan Dana Repatriasi

c. Peningkatan Kepatuhan Wajib Pajak.

Penegakan hukum perpajakan pasca tax amnesty menurut Buckwalter et.al. diperlukan untuk menghindari manipulasi laporan keuangan perusahaan pada kasus Wajib Pajak perusahaan atau Badan. Tax amnesty tanpa disertai penegakan hukum akan mengakibatkan

\footnotetext{
${ }^{43}$ Rochmat Soemitro, Asas dan Dasar Perpajakan 1, (Bandung: Refika Aditama, 1998), hlm. 80 .
} 
kepatuhan dari Wajib Pajak tidak meningkat bahkan cenderung menurun. ${ }^{44}$

Tabel 7. Rasio Kepatuhan Penyampaian SPT Tahunan PPh Tahun 2013 s.d. 2017.

\begin{tabular}{|l|l|r|r|r|r|r|}
\hline No & \multicolumn{1}{|c|}{ Uraian } & \multicolumn{1}{c|}{$\mathbf{2 0 1 3}$} & $\mathbf{2 0 1 4}$ & $\mathbf{2 0 1 5}$ & $\mathbf{2 0 1 6}$ & $\mathbf{2 0 1 7}$ \\
\hline 01. & $\begin{array}{l}\text { Wajib Pajak } \\
\text { Terdaftar }\end{array}$ & $24,347,763$ & $27,379,256$ & $30,044,103$ & $32,769,215$ & $33,468,781$ \\
\hline 02. & $\begin{array}{l}\text { Wajib Pajak } \\
\text { Terdaftar Wajib } \\
\text { SPT }\end{array}$ & $17,731,736$ & $18,357,833$ & $18,159,840$ & $20,165,718$ & $23,318,565$ \\
\hline 03. & $\begin{array}{l}\text { Target Rasio } \\
\text { Kepatuhan (\%) }\end{array}$ & $65.00 \%$ & $70.00 \%$ & $70.00 \%$ & $72.50 \%$ & $50 \%$ \\
\hline 04. & $\begin{array}{l}\text { Target Rasio } \\
\text { Kepatuhan - } \\
\text { SPT (3x2) }\end{array}$ & $11,525,628$ & $12,852,301$ & $12,711,888$ & $14,620,146$ & $11,659,283$ \\
\hline 05. & Realisasi SPT & $9,966,833$ & $10,852,301$ & $10,972,336$ & $12,735,463$ & $14,720,966$ \\
\hline 06. & $\begin{array}{l}\text { Rasio } \\
\text { Kepatuhan (5:2) }\end{array}$ & $56.21 \%$ & $59.12 \%$ & $60.42 \%$ & $63.15 \%$ & $62.96 \%$ \\
\hline
\end{tabular}

Sumber: Laporan Kinerja DJP 2013-2017. ${ }^{45}$

Sebenarnya target tersebut dapat dikatakan realistis mengingat banyaknya kebocoran pajak yang terjadi dan membuat penerimaan perpajakan tidak bisa optimal. Setidaknya terdapat tiga permasalahan yang membuat penerimaan perpajakan menjadi tidak optimal. Pertama, masih rendahnya tingkat kepatuhan masyarakat dalam membayar pajak. ${ }^{46}$ Data dalam tabel 5 menunjukkan bahwa tahun 2017 dari 33 juta potensi penduduk yang bisa mendapatkan Nomor Pokok Wajib Pajak (NPWP), baru sekitar 23 juta yang sudah memiliki NPWP. Artinya hanya sekitar $50 \%$ orang yang memiliki NPWP dari total potensi penduduk yang memiliki NPWP. Dari jumlah tersebut, tidak

\footnotetext{
${ }^{44}$ Rosan Roeslani, Amnesti Pajak sebagai Momentum Penguatan Fiskal dan Membangun Daya Saing Ekonomi, dalam Djokosoetono Research Center, Amnesti Pajak Efektivitasnya Bagi Pembiayaan Pembangunan Berkelanjutan, (Depok: adan Penerbit Fakultas Hukum Universitas Indonesia, 2016), hlm. 41.

${ }^{45}$ Tanpa Pengarang, Laporan Kinerja Direktorat Jenderal Pajak Tahun 2013 s.d. 2017, http://www.pajak.go.id/buletin-kinerja, diakses tanggal 7 Agustus 2018 pukul 09.00 WIB.

${ }^{46}$ Rosan Roeslani, Op.Cit., 2016, hlm. 33
} 
semua orang yang memiliki NPWP secara sadar menyampaikan pajaknya. Demikian juga dengan kepatuhan penyampaian pajak yang masih rendah, hanya 62,96\% dari jumlah Wajib Pajak terdaftar di tahun 2017 yang lebih rendah dari tahun 2016.

Jadi kepatuhan Wajib Pajak pada tahun 2017 belum meningkat dikarenakan kepatuhan Wajib Pajak turun 0,19\% dari kepatuhan Wajib Pajak pada tahun 2016 yang telah mencapai $63,15 \%$ turun menjadi 62,96\% pada tahun 2017.

d. Penurunan Tunggakan Pajak

Adanya program pengampuan pajak (tax amnesty), pemerintah menghapus pajak terutang dan sanksi administrasi perpajakan bagi Wajib Pajak Orang Pribadi dan Badan yang belum menjadi Wajib Pajak juga bisa mendapat penghapusan sanksi pidana dibidang perpajakan atas harta yang belum dilaporkan dalam SPT, dengan cara melunasi seluruh tunggakan pajak yang dimiliki dan membayar uang tebusan. ${ }^{47}$

Tabel 8. Tunggakan Pajak Tahun 2013 s.d. 2017

\begin{tabular}{|c|c|c|c|c|}
\hline \multirow{2}{*}{ Tahun } & \multicolumn{2}{|c|}{ Pajak } & Kumlah & \multicolumn{2}{|c|}{ Nominal Ketetapan } \\
\cline { 4 - 5 } 2013 & $\begin{array}{l}\text { Jenis Ketetapan } \\
\text { Pajak ( SKPKB, } \\
\text { SKPLB, SKPN) }\end{array}$ & 32.302 & 84.888 .416 .908 .075 & 2.485 .925 .825 \\
\cline { 2 - 5 } & $\begin{array}{l}\text { Jenis Sengketa Pajak } \\
\text { ( Non Keberatan, } \\
\text { Keberatan, Banding, } \\
\text { Peninjauan Kembali) }\end{array}$ & 32.302 & 84.888 .416 .908 .075 & 2.455 .925 .814 \\
\cline { 2 - 5 } 2014 & $\begin{array}{l}\text { Jenis Pajak (PPh 21, } \\
\text { 22, 23, final, PPnBM, } \\
\text { dll) }\end{array}$ & 32.302 & 83.741 .416 .908 .075 & 2.485 .925 .826 \\
\hline & $\begin{array}{l}\text { Jenis Ketetapan } \\
\text { Pajak ( SKPKB, } \\
\text { SKPLB, SKPN) }\end{array}$ & 42.504 & 89.699 .566 .865 .405 & 3.979 .300 .588 \\
\cline { 2 - 5 } & $\begin{array}{l}\text { Jenis Sengketa Pajak } \\
(\quad \text { Non Keberatan, }\end{array}$ & 42.504 & 89.699 .566 .845 .405 & 3.979 .291 .588 \\
\hline
\end{tabular}

${ }^{47}$ Erna Widjajati,Op.Cit., 2016, hlm. 76. 


\begin{tabular}{|c|c|c|c|c|}
\hline \multirow{4}{*}{ Tahun } & \multirow{2}{*}{ Pajak } & \multirow{2}{*}{$\begin{array}{l}\text { Jumlah } \\
\text { Ketetapan }\end{array}$} & \multicolumn{2}{|c|}{ Nominal Ketetapan } \\
\hline & & & $\mathrm{Rp}$ & USD \\
\hline & $\begin{array}{l}\text { Keberatan, Banding, } \\
\text { Peninjauan Kembali) }\end{array}$ & & & \\
\hline & $\begin{array}{l}\text { Jenis Pajak (PPh 21, } \\
\text { 22, 23, final, PPnBM, } \\
\text { dll) }\end{array}$ & 42.504 & 89.699.566.875.406 & 3.979.300.527 \\
\hline \multirow{3}{*}{2015} & $\begin{array}{l}\text { Jenis } \\
\text { Pajak (retetapan } \\
\text { SKPLB, SKPN })\end{array}$ & 138.557 & 108.681.382.657.952 & 3.721.356.942 \\
\hline & $\begin{array}{l}\text { Jenis Sengketa Pajak } \\
\text { ( Non Keberatan, } \\
\text { Keberatan, Banding, } \\
\text { Peninjauan Kembali) }\end{array}$ & 138.557 & 108.681.382.657.952 & 3.722 .386 .942 \\
\hline & $\begin{array}{l}\text { Jenis Pajak (PPh 21, } \\
\text { 22, 23, final, PPnBM, } \\
\text { dll) }\end{array}$ & 138.557 & 90.903 .852 .456 .810 & 3.722 .386 .942 \\
\hline \multirow{3}{*}{2016} & $\begin{array}{lr}\text { Jenis } & \text { Ketetapan } \\
\text { Pajak ( } \quad \text { SKPKB, } \\
\text { SKPLB, SKPN })\end{array}$ & 59.983 & 119.127.549.649.867 & 218.816 .944 .340 \\
\hline & $\begin{array}{l}\text { Jenis Sengketa Pajak } \\
\text { ( Non Keberatan, } \\
\text { Keberatan, Banding, } \\
\text { Peninjauan Kembali) }\end{array}$ & 59.983 & 118.127 .549 .649 .867 & 4.909.575.572 \\
\hline & $\begin{array}{l}\text { Jenis Pajak (PPh 21, } \\
\text { 22, 23, final, PPnBM, } \\
\text { dll) }\end{array}$ & 79.319 & 38.436 .420 .124 .123 & 1.084 .451 .178 \\
\hline \multirow{3}{*}{2017} & $\begin{array}{lr}\text { Jenis } & \text { Ketetapan } \\
\text { Pajak ( } \quad \text { SKPKB, } \\
\text { SKPLB, SKPN })\end{array}$ & 124.484 & 58.096.307.078.621 & 679.281 .440 \\
\hline & $\begin{array}{l}\text { Jenis Sengketa Pajak } \\
\text { ( Non Keberatan, } \\
\text { Keberatan, Banding, } \\
\text { Peninjauan Kembali) }\end{array}$ & 63.678 & 124.747.488.967.598 & 5.425.979.957 \\
\hline & $\begin{array}{l}\text { Jenis Pajak (PPh 21, } \\
\text { 22, 23, final, } P P n B M\end{array}$ & 124.484 & 58.096.307.078.621 & 679.281 .440 \\
\hline
\end{tabular}




\begin{tabular}{|l|l|c|c|c|}
\hline \multirow{2}{*}{ Tahun } & \multirow{2}{*}{ Pajak } & Jumlah & \multicolumn{2}{|c|}{ Nominal Ketetapan } \\
\cline { 3 - 4 } & & Ketetapan & Rp & USD \\
\cline { 2 - 4 } & dll) & & & \\
\hline \multicolumn{2}{|c|}{ Sumber : Laporan KeuanganDJP 2013-2016 (datadiolah) ${ }^{48}$} \\
\hline
\end{tabular}

Tabel 8 menunjukkan jumlah tunggakan pajak pada tahun 2016 telah mengalami penurunan yaitu sebesar 199.285 Wajib Pajak dengan rincian (jenis ketetapan pajak sebesar 59.983 wajib pajak, jenis sengketa pajak sebesar 59.983 Wajib Pajak, jenis pajak 79.319 Wajib Pajak) dibandingkan tahun 2017 dengan jumlah tunggakan pajak sebesar 312.646 Wajib Pajak.

\section{Urgensi KeadilanDalam Implementasi Program Pengampunan Pajak (Tax Amnesty)}

Keadilan sebagai fairness, posisi kesetaraan asli berkaitan dengan kondisi alam dalam teori tradisional kontrak sosial. Posisi asal ini tentu tidak dianggap sebagai kondisi historis, apalagi sebagai kondisi primitif kebudayaan. Ia dipahami sebagai situasi hipotesis yang dicirikan mengarah pada konsepsi keadilan tertentu. Teori Keadilan bisa dibagi menjadi dua bagian utama : (1) penafsiran atas situasi awal dan perumusan berbagai prinsip yang bisa dipilih, serta (2) Suatu argumentasi yang menyatakan prinsip mana yang bisa digunakan. Dua prinsip tersebut berbunyi demikian: pertama, setiap orang mempunya hak yang sama atas kebebasan dasar yang paling luas, seluas kebebasan yang sama bagi semua orang. Kedua, ketimpangan sosial dan ekonomi mesti diatur sedemikian rupa sehingga (a) dapat diharapkan memberikan keuntungan semua orang, dan (b) semua posisi dan jabatan terbuka bagi semua orang. ${ }^{49}$

Implementasi program pengampunan pajak(tax amnesty)juga harus sesuai dengan nilai-nilai yang terkandung dalam Pancasila. Pancasila berisi nilai fundamental dan sebagai karakteristik dasar Bangsa Indonesia. Dalam ilmu hukum, Pancasila merupakan sumber dari segala sumber hukum, oleh karena itu, setiap produk hukum harus menyesuaikan diri dengan Pancasila.

${ }^{48}$ Tanpa Pengarang, Laporan Keuangan DJP 2013-2016, http://www.pajak.go.id/laporan-keuangan-djp, diakses tanggal 21 Agustus 2018, Pukul 17.00 WIB.

${ }^{49} \mathrm{John}$ Rawls, A Theory of Justice Teori Keadilan Dasar-Dasar Filsafat Politik untuk Mewujudkan Kesejahteraan Sosial dalam Negara, (Yogyakarta: Pustaka Pelajar, 2011), hlm. $13,65,72$. 
Pancasila sebagai falsafah bangsa mengandung nilai yang bersifat subjektif dan objektif. Sebagai nilai yang bersifat objektif memiliki sifat ${ }^{50}$ :

a. Rumusan dari sila-sila Pancasila itu sendiri menunjukan adanya sifatsifat abstrak, umum dan universal;

b. Inti dari nilai-nilai Pancasila akan tetap ada sepanjang masa dalam kehidupan bangsa Indonesia dan mungkin juga pada bangsa lain, baik dalam adat istiadat, kebudayaan, kenegaraan, maupun dalam hidup keagamaan dan lainnya.

Apabila kita melihat Pancasila yang merupakan dasar Negara Indonesia dan menjadi landasan filosofis semua kegiatan penyelenggaraan negara, maka pemungutan pajak oleh negara kepada rakyatnya tersebut dapat dibenarkan jika kita mengacu pada sila kelima yaitu keadilan sosial bagi seluruh rakyat Indonesia. Sila kelima Pancasila tersebut mengandung makna bahwa kita perlu mengembangkan perbuatan-perbuatan yang luhur yang mencerminkan sikap dan suasana kekeluargaan dan kegotong-royongan.

Pajak adalah salah satu bentuk perbuatan gotong-royong yang tidak perlu disyaratkan, melainkan sudah hidup dan berkembang dalam masyarakat Indonesia yang hanya perlu dikembangkan dan dilestarikan saja. Gotong royong, termasuk di dalamnya membayar pajak merupakan salah satu pengorbanan setiap anggota masyarakat untuk kepentingan bersama tanpa mendapatkan imbalan. Jadi, pemungutan pajak menurut Pancasila dapat dibenarkan, karena pembayaran pajak akhirnya adalah untuk kita bersama.Sesuai dengan asas falsafah hukum, bahwa setiap hukum dimaksudkan untuk mencapai keadilan bagi masyarakat, dengan demikian hukum haruslah mengacu kepada keadilan, begitu juga halnya dengan hukum pajak.

Negara harus mengusahakan semua prasyarat, kondisi, prasarana agar masyarakat dapat hidup dengan adil dan sejahtera. ${ }^{51}$ Meminjam pendapat W. Friedman, ${ }^{52}$ tugas tersebut memiliki konsekuensi bahwa negara harus berfungsi baik sebagai penyedia (provider) kesejahteraan rakyat, sebagai pengatur (regulator), negara sebagai pengusaha (entrepreneur)dalam

${ }^{50}$ Teguh.Op.Cit. hlmn 19-20

${ }^{51}$ Franz Magnis-Suseno, Etika Politik Prinsip-prinsip Moral Dasar Kenegaraan Modern, (Jakarta: Gramedia Pustaka Utama, 1994), hlm.316.

${ }^{52}$ Sering disebut dengan istilah negara ekonomi campuran, lihat W. Friedman, The State and The Rule of Law in A Mixed Economy, London: Steven and Sons, 1971, hlm. 3; Bandingkan dengan Abrar Saleng, Loc. Cit., hlm. 16; lihat Suteki, Loc.Cit. 
pembangunan ekonomi maupun dalam menjalankan sektor-sektor tertentu melalui badan usaha milik negara (BUMN) dan negara sebagai wasit (umpire) untuk merumuskan standar-standar yang adil mengenai sektor ekonomi dalam rangka Pembangunan Nasional dan Tujuan Nasional termasuk dalam penataan dan pengelolaan kebijakan sektor perpajakan yang adalah penyumbang utama penerimaan negara untuk mewujudkan kesejahteraan rakyat. 


\section{DAFTAR PUSTAKA}

\section{Buku-Buku}

Arief Sidharta (Penerjemah), Meuwissen Tentang Pengembanan Hukum, Ilmu Hukum, Teori Hukum, dana Filsafat Hukum, (Bandung : Refika Aditama, 2007.

Brian Z. Tamanaha, A General Jurisprudence of Law and Society, (New York : Oxford University Press, 2006).

Djokosoetono Research Center, Amnesti Pajak Efektivitasnya Bagi Pembiayaan Pembangunan Berkelanjutan, (Depok: Badan Penerit Fakultas Hukum Universitas Indonesia, 2016).

Kaelan, M.S.H.,Negara Kebangsaan Pancasila, Cultural, Historis, Filosofis, Yuridis Dan Aktualisasinya", (Yogyakarta: Paradigma, 2013).

Mahmutarom H.R., Rekonstruksi Konsep Keadilan Studi tentang Perlindungan Korban Tindak Pidana dalam Hukum Positif, Hukum Islam, Konstruksi Masyarakat dan Instrumen Internasional, Cetakan I, (Semarang: Badan Penerbit Universitas Diponegoro, 2010).

Mulyodiwarno, Nuryadi, Menakar Kesetaraan Hak dan Kewajiban Perpajakan di Indnoesia Seri 2, (Depok: RajaGrafindo Persada, 2018).

Philippe Nonet \& Selznick,Law and Society in Trantition, (New York: HarperColophon Books,1978).

Revrisond Baswir, Demokrasi ekonomi, (Malang: Averroes Press: tanpa tahun).

Robert K. Yin, Studi Kasus, Desain dan Metode, (Jakarta : Radja Grafindo, 2006).

Romli Atmasasmita, Teori Hukum Integratif, Rekonstruksi terhadap Teori Hukum

Pembangunan dan Teori Hukum Progresif, (Tanpa Kota Terbit: Genta Publishing, 2012).

RochmatSoemitro, Pengantar Singkat Hukum Pajak,(Bandung:Eresco, 1988).

Rochmat Soemitro \& Dewi Kania, Asas dan Dasar Perpajakan Jilid 1 Edisi Revisi, (Bandung, Refika Aditama, 2004).

Satjipto Rahardjo, Ilmu Hukum,(Bandung: Citra Aditya Bakti; 1966).

Satjipto Rahardjo, Ilmu Hukum: Pencarian, Pembebasan dan Pencerahan (Editor Khudzaifah Dimyati), (Surakarta : Muhammadiyah University Press, 2004).

Satjipto Rahardjo, Penegakan Hukum Suatu Tinjauan Sosiologis, (Yogyakarta: Genta Publishing, 2009).

Soehino, Hukum Tata Negara Teknik Perundang-Undangan (Setelah Perubahan Pertama dan Perubahan Kedua Undang-Undang Dasar Negara Republik Indonesia Tahun 1945),(Yogyakarta: BPFE, 2006). 


\section{Website}

ATS Consulting, Sunset Policy Jilid I dan Jilid II, https://www.atskonsultama.com/jawaban/sunset-policy-jilid-i-dan-jilid-ii, diakses tanggal 17 Oktober 2018, pukul 16.00 WIB.

James Alm, Jorge Martinez-Vazquez, dan Sally Walace, "Do Tax Amnesties Work?:

The Revenue Effects of Tax Amnesties During the Transition of Russian Federation", Economic Analysis and Policy Vol 39,(September 2009):249. Diakses E-book pada tanggal 22 Mei 2015.

Lily Rusna Fajriah, Dua Negara Ini Bisa Jadi Contoh Keberhasilan Tax Amnesty, https://ekbis.sindonews.com/read/1103450/33/dua-negara-ini-bisa-jadicontoh-keberhasilan-tax-amnesty-1461402051, diakses tanggal 14 November 2018, pukul 18.27 WIB. 